\title{
オージェ電子利得の絶対測定 $(\mathrm{I}) *$ —MAA の設計一
}

\author{
後藤 敬典**. 岩田 弘**. 境 悠治***
}

(昭和63年 8 月 8 日. 受理)

\author{
Measurements of Absolute Auger Electron Yield (I) \\ -A New Design of CMA- \\ Keisuke GOTO**, Hiroshi IWATA** and Yuzi SAKAI*** \\ ** (Nagoya Institute of Technology Gokiso-cho, Showa-ku, Nagoya 466) \\ ***(JEOL, Musashino 3-1-2, Akishima Tokyo 196)
}

(Received August 8, 1988)

\begin{abstract}
A new cylindrical mirror analyzer (CMA) was designed to measure the absolute Auger electron yield and to offer the standard spectra in the Auger electron spectroscopy (AES). An ideal logarithmic potential distribution, which is the heart of the CMA, can be attained by only adjusting the location of the potential gap at the both ends of the CMA without using conventional fringing field correcting electrodes. The effects of residual magnetic field was also discussed and the attenuation characteristics of the $\mu$-metal shield was presented.
\end{abstract}

\section{1. はじめに}

Pierre Auger による最初の短い論文（1923年) ${ }^{1}$ に端を 発するオージェ電子分光法（AES）は，この手法が 1930 年代に表面元素分析法として有力なものとなろらという 指摘がありながら1960年代まではほとんど取上げられな かった. しかし1960年代の中頃から半導体の研究と超高 真空技術の進歩とが相待って AES は急速に進歩し内外 のメーカによる装置類も既に完成の域に達した感があ る.このあたりの背景は他で詳しく述べてあるので関心 の向きは参照されたい2).このよらに既に完成の域にあ る表面分析法であるがその定量性は多くの研究者の努力 にもかかわらずはなはだ心もとなく，かなりいい条件の ときでさえ，未だに20\%あたりでその開発期の水準以上 には進歩していない，例えばアメリカにおけるラウンド ロビンの結果では，はなはだしいものにおいては 2 析以 上のスペクトルの強度の違いも報告されている3).この

\footnotetext{
* 昭和 63 年 3 月 29 日 第 35 回応用物理関係連合講演会にて発表, $29 \mathrm{aS} 7 /$ II

** 名古屋工業大学 ( $\mathbf{\mp} 466$ 名古屋市昭和区御器所町 $)$

*** 日本電子(侏)（干196 東京都昭島市武蔵野3-1-2）
}

よらな事情に鑑み，AES を含さ表面化学分析の国際協 力の一環としてVAMAS-SCA (Verseilles Projects on Advanced Materials and Standards-Surface Chemical Analysis）が組織され，日本に於ても官学民の 21 の機関から専 門家が集りこの問題に取組んでいる4). 我々が金材研で 作製した金銅合金による結果も例外ではなく，専門家が 最大限の努力を払って測定したにもかかわらず，ピーク 強度の違いは数倍にも達している5).

従来発表されている AES のハンドブックやデータ集 はすべてある特定の機種を用いて測定した相対的なスぺ クトルであり，入射 1 次電子線に対する絶対的な利得を 測った例は皆無である。このように基準となる標準スぺ クトルを持たずに定量性を論じてもその結果は常に曖昧 さを含んでいることになる.

この研究の目的は日本側 VAMAS-SCA の検討結果を もとに, 科学技術庁の科学技術振興調整費の援助を得 て, オージェ電子スペクトルの絶対值を得る為の分析器 を実現し標準スペクトルを提供するところにある．研究 は現在製作途上で未完成ではあるがその設計段階につい て述べる。 


\section{2. 分析器の選択}

AES 用の分析器としては現在大きく分けて 3 つのタ イプがある.それらのらちで同心円筒型ェネルギー分析 器 (CMA) が最も一般的に普及しており, 次にX 線光 電子分光用の静電レンズ系と半球型偏向器を組合せた ESCA と兼用のものが使われている.1960年代に研究室 的に広く使われていた 3（又は4）枚グリッドによる低 速電子線回折（LEED）観察とAESを兼用したいわゆ る Germer 型-LEED-AES 装置は本質的にショット雑 音が大きく, 更にグリッドからの 2 次電子の影響, 2 次 電子増倍管の使用が困難なために感度が低いといら久点 があるために AES として用いられることはほとんどな くなり本来の目的に使われている.

オージェ電子の絶対測定の為の標準となる分析器とし ては以下の要素が備わっていることが必要である：

1. 収率の計算が可能なこと,

2. 理論にもとづいて製作すれば必ずそれに合った性 能が得られること,

3. 構成要素が少く, 機械加工が容易なこと,

4. 磁気シールド及び磁場補償が容易なこと,

5. 一般に広く使われている型であることが好まし い.

以上の項目を総合すると CMA が第 1 候補に挙ってく る.

CMA はその名の示す如く，すべてが軸対称にできて おり機械的な精度を出すことが容易で組立調整も比較的
楽である. 分析器としての基本性能である分解能と収率 をみてる，例えば一般的に使われている入射角 $42^{\circ} 18.5^{\prime}$ $\pm 6^{\circ}$ についてみると, CMA のスリットを最適な位置 （3 次収束）に選ぶと0.2〜0.3\%が得られ，またこのとき の収率は全放出量の約 $10 \%$ が得られる.これらの值を半 球型のものと比べてみると, 分解能については 1 桁近く 優れており6), 収率については条件が異なるので比較は むずかしいがほぼ同一である，な拉市販の ESCA 装置 は上記よりはるかに高いエネルギー分解能を有している が，これはレンズ系で入射電子のエネルギーを減速 (5〜100 eVに) して半球型偏向器に入れている為で, 半球型偏向器単独の分解能ではないことに注意された い.

CMA は理論的に7,8,9)に解明されておりまたシミュレ ーション10) も比較的容易であり, しかも外部磁場を遮幣 するための磁気シールドも理想に近いものが可能であ る. 以上のことを総合してオージェ分析器としては GMAを選んだ.

\section{CMA の基本的特性}

CMA の基本的な構成は二つの無限に長い同軸円筒間 に生ずる対数関数的な電場空間を入射電子に対して逆電 位となるよらになされている。このときの入射電子の軌 道は解析的に解かれており，また大型計算機を用いて軌 道を追跡した結果も十分な精度で前者の結果と一致して いる. 我々が解析解9 をもとに PC-9801を用いてルン ゲタック法によるプログラムで求めた例の 1 部を GMA

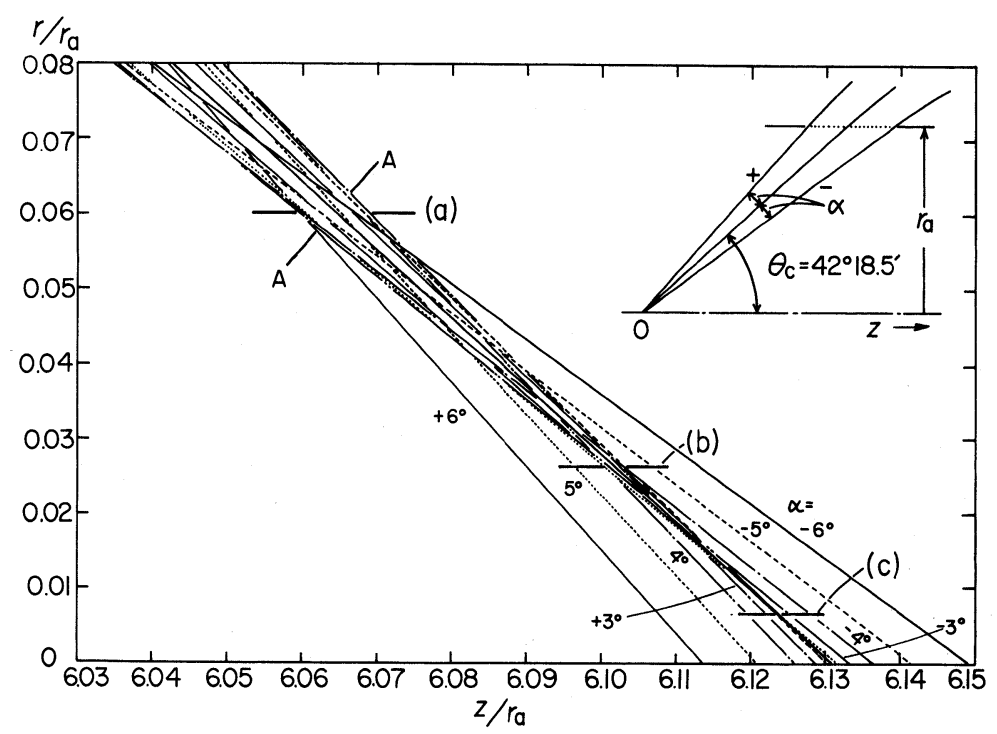

Fig. 1 Focussing properties of CMA; excit slit positions for acceptance angle of (a) $\alpha=6^{\circ}$, (b) $\alpha=4^{\circ}$, and (c) $\alpha=2^{\circ}$. 
のイメージ側について Fig. 1 に示す.

これは既に発表されているもの6,7) と同一のものであ るが、これから新たに設計しようとするときの一助にな ると思い，その収束状況を詳しく示した。図は最適入射 角 $\left(\theta_{\mathrm{c}}=41^{\circ} 18.5^{\prime}\right)$ を中心に $1^{\circ}$ 間隔で $\pm 6^{\circ}$ の実用的な CMA について示してある. スケールは CMA の内円筒 の外径 $r_{\mathrm{a}}$ との比で示してある.この図をもとに入射ビ 一ムの太さが最小となる位置にその大きさのスリットを 置けば最適な CMA ができる.

図からわかるように電子線の拡がりは軸上の像の位置 にスリットを設けた場合に比べて軌跡の束が最もくびれ る最適位置に設けると約 3.5 分の 1 小さくなり, それに 応じて実効的 (半值幅) なエネルギー分解能も3.5倍向 する.これは CMA が最適スリット位置では 3 次の収束 をするためでありこの特性は同一入射角について $180^{\circ}$ 半 球型と比べると約 1 桁よく特に重要である6,7).

またエネルギー分解能と入射角の関係は $\theta_{\mathrm{c}}$ よりの広 き角を $\alpha$ とすると $\alpha^{3}$ に比例して向上しており $\alpha=6^{\circ} て ゙$ は2.4 $\times 10^{-3}$ (この值は軌道追跡法でシミュレートした 結果とほぼ一致している6,10), $\alpha=4^{\circ}$ では6.7 $\times 10^{-4}$, さ らに $\alpha=2^{\circ}$ になると $8 \times 10^{-5}$ と信じ難い程に向上する. これらの関係は文献に詳しく述べられている7).

以上のシミュレーションは試料上の理想的な 1 点から 放出された電子についてみてきたが, 次にこの点が軸上 と軸から垂直 (径) 方向に移動した場合の理想值からの ずれを軌道追跡の結果 ${ }^{10)}$ からみる. 試料上の点が軸方向 及び径方向にそれぞれ $\Delta S_{\mathrm{z}}$ 及び $\Delta S_{\mathrm{r}}$ ずれたとするとこれ らはそれぞれエネルギーの誤差即ち $\Delta E_{\mathrm{z}} / E=0.18 \times \Delta E_{\mathrm{z}}$ $/ r_{\mathrm{a}}$ 及び $\Delta E_{\mathrm{r}} / E=-0.20 \times \Delta S_{\mathrm{r}} / r_{\mathrm{a}}$ となる。般的な CMA の值である $r_{\mathrm{a}}$ を $20 \mathrm{~mm}$ として $\Delta S_{\mathrm{z}}$ 及び $\Delta S_{\mathrm{r}}$ がそ れぞれ $0.2 \mathrm{~mm}\left(r_{\mathrm{a}} / 100\right)$ ずれたとすると $2000 \mathrm{eV}$ のル ギーに対して $\Delta E_{\mathrm{z}}=3.6 \mathrm{eV}$ 及び $\Delta E_{\mathrm{r}}=-4.0 \mathrm{eV}$ の誤差を 与えるが，これらの值は CMAのエネルギー分解能に近 いものである.なお $\Delta E_{\mathrm{r}}$ は 1 方向についてのみの計算 であり実際の分析ではこの方向は円周方向に亘るのでこ の值は直接適用できないが 1 つ指針になる.

\section{CMA の軌道空間の実現}

これまでの計算及びシミュレーションのすべては理想 的な電界, 即ち対数関数, が分析空間で実現されている ものとして行ってきた．この状態を実現するには $r_{\mathrm{a}} に$ 比べて十分長い長さの円筒を用いねばならずこれは現実 的ではない，従ってこの筒の長さを可能な限り短くする 為の工夫が各製造者により成されており，この技術の良 否が性能を大きく決める. 例えば短くした円筒の両端に リング状の電極を配し各電極に抵抗分割でその位置に見
合ら電位を与えるもの（一般的），あるいは中心をくり 抜いた㿼状のセラミックに半導体の抵抗体を塗布したも の (Physical Electronics 社) などがある.ついでながら このとき補正電極の支持などに使ら絶緑物が直接分析空 間に露出しているとその部分の充放電によりスペクトル が大さく影響を受けることが多々ありこの絶縁物の処理 は重要である。

従来の補正法では技術的に不確定な要素が含まれ, 分 析空間は理想的な電位分布からずれてくることは十分考 えられ購入時の “当りはずれ”が生ずる要因の 1 つであ る.この電位の䛊差を例えば今回考えている $0.1 \%$ 誤 差に納めることは上記のいずれの補正によっても不可能 と考えられる，従って我々は従来の方法に依らずに，筒 の長さは多少長くなるが, 幾何学的形状により自然（静 電的）に決まる電位分布を考え, 筒の形状を工夫してみ ることにした.これがこの研究に於て最も重要な点であ る.

無限に長い同心円筒（Fig. 2(a)）の内円筒の外径と 電位をそれぞれ $r_{\mathrm{a}}(=0)$ とし外円筒の内径と電位を同 様に $r_{\mathrm{b}}$ と $V_{\mathrm{b}}$ とすると, 半径 $r\left(r_{\mathrm{a}} \leq r \leq r_{\mathrm{b}}\right)$ 上の電位 $V_{\mathrm{r}}$ は,

$$
V_{\mathrm{r}}=V_{\mathrm{b}} \ln \left(r / r_{\mathrm{a}}\right) / \ln \left(r_{\mathrm{b}} / r_{\mathrm{a}}\right)
$$

で与えられる.これが理想的な電位であり, CMAの分

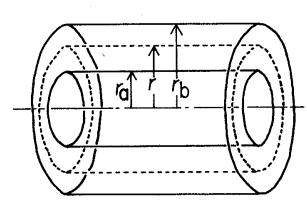

(a)

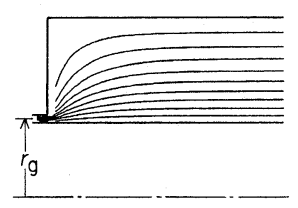

(c)

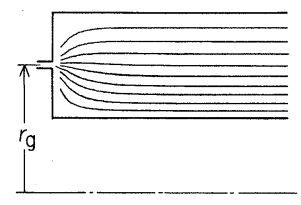

(e)

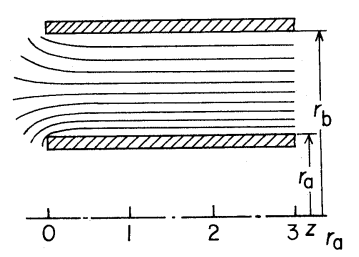

(b)

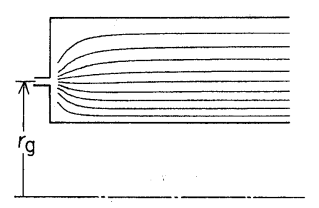

(d)

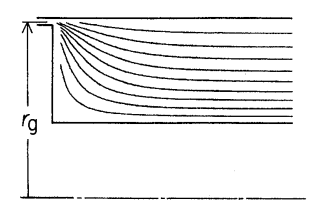

(f)
Fig. 2 CMA with infinite length coaxial cylinders (a) , fringing field of the finite length (b), closed-end but with potential gaps (c) to (f). 
析空間はこの電位になっていなければならない.

次に今回の目的である筒を短くし更に端面の形状を工 夫することにより上記の電位分布を分析空間に於て実現 することを試みる，この場合電位分布は解析的には求ま らないので日本電子に設置されている大型コンピュータ を用いて境界要素法により求めた。な拈計算を実行する のに必要な領域, 電極の分割法などの詳細は省略する. 電位分布は内円筒の電位を“ 0 ”として外円筒のそれを “1”としてこの間を10等分して各々の等電位線を示し たのが Fig. 2(b)-(f)である. 電極形状としてはすべて 軸対称でしかも軸方向電極の中心に対しても対称なもの を考えているので, 図は左側 $1 / 4$ を示してある. Fig. 2(b) は単に筒長を短くしたものでフリンジング効果と してょく見かける例である。このように簡単な系でも筒 の端面から円筒の半径の $1 / 2$ の距離だけ軸方向に入った 位置ではまだ等電位線の曲りが認められるが, 更に進ん で半径 $\left(r_{\mathrm{a}}\right)$ の距離になるとそのあたりからは等電位線 はほぼ平行になっておりすでに実用的な CMA の電位分 布としては十分なものが得られているのがわかる. しか しながらこれを CMA として使らには両円筒を固定する 為の支持及び外部から混入するイオンや電子などに対す る対策あるいは磁気シールドなどを施せねばならず，こ こで得られた電位分布は乱されてしまら。CMAを

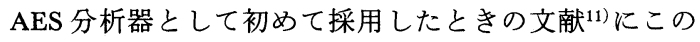
ような GMA が示されているが端面は果してどのようで あったかは不明である（b)を CMA として使うには両 端は何らかの形で電位差を設ける為のギャップを残して 閉じて拐かねばならない。このシミュレーションをした のがFig. 2 の(c) から(f)である.ここでは $r_{\mathrm{a}}=1, r_{\mathrm{b}}=$ 2.4 , 電位差を設ける為の同心円状のギャップを 0.1 , ギ ャップの中心の半径を $r_{\mathrm{g}}$ として示してある. ギャップ 半径 $r_{\mathrm{g}}$ は内円筒に近い方から順に，(c)内円筒に隣接し $\tau$, (d) 算術平均の $\sqrt{r_{\mathrm{a}} r_{\mathrm{b}}},(\mathrm{e})$ 幾何平均の $\left(r_{\mathrm{a}}+r_{\mathrm{b}}\right) / 2$, (f) 外円筒に隣接させたものである.なお (d) ・ (e) と類 似の構造が CMA の出口側に用いられた報告 ${ }^{12)}$ がある が, 最適設計かどらかは定かでない.これらのらち両極 端にギャップを設けた (c) と (f) は理想值への収束が遅い のがわかる.（d）はギャップの中心の電極がほぼ直線と なるので収束が速いことを期待したものである．（e）に ついても収束の速さを期待したものである. 我々がここ で期待しているのは単なる全体的な収束の速さではな く, 実際に電子が飛行する分析空間に和ける理想値への 収束の速さである. 即ち電子は内円筒側から入射するの で, 内円筒に近い方から順に理想值に収束していくのが 好ましい。詳しい図を見れば電位分布の誤差として $1 \%$ 位までは検出できるが，これを $0.1 \%$ とする，すでに

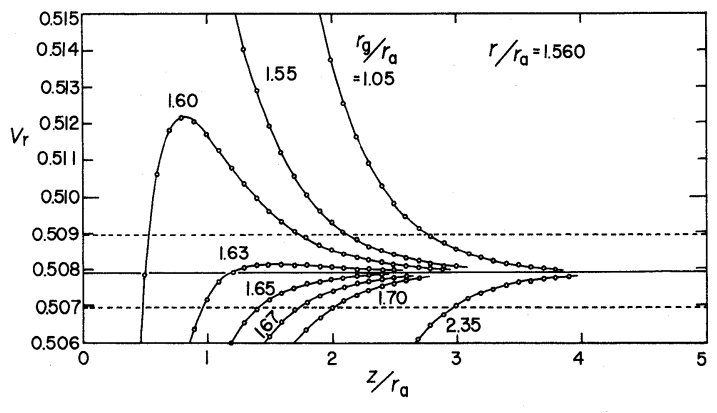

Fig. 3 Potential distribution at $r / r_{\mathrm{a}}=1.560$ for gap radii $r_{\mathrm{g}} / r_{\mathrm{a}}$ as a function of distance $z / r_{\mathrm{a}}$ from the fringe.

肉眼では判別できず，更に詳しいもので評価しなければ ならない，なおこの電位誤差 $0.1 \%$ は $r_{\mathrm{b}} / r_{\mathrm{a}}$ の工作精度に 換算すると同じく $0.1 \%$ となり，これは今回試作予定の 総合的な工作精度（50〜100 $\mu \mathrm{m} ）$ に相当する值である.

電位分布を更に詳しく検討するために，空間を同心円 状に10分割し, 各半径上の電位をギャップの半径 $r_{\mathrm{g}}$ を パラメータとして端面からの距離 $\left(z / r_{\mathrm{a}}\right)$ の関数として 求めた．計算の 1 例として $r / r_{\mathrm{a}}=1.560$ について求めた ものを Fig. 3 に示す。このときの理想值は0.50794とな るがこれを実線で，またこの值から $\pm 0.1 \%\left(V_{\mathrm{b}}-V_{\mathrm{a}}\right.$ の) の範囲を点線で示す. 特性は $z / r_{\mathrm{a}}$ の小さい端に近い方 からこの範囲に入っているものが収束が速いといらこと になる. 図の特性は一様ではなく極大值をもつものもあ るが，予期した如く $r_{\mathrm{g}}=1.55$ (算術平均) と $r_{\mathrm{g}}=1.70$ (幾 何平均）の間に最適なものがありそうである. 図の $r=$ 1.560 上の特性をみる限りではギャップを半径 $r_{\mathrm{g}} / r_{\mathrm{a}}=$ 1.63 あたりに選ぶと最適であり，筒の端面より内円筒 の半径の距離も進めばすでに $0.1 \%$ 電位空間になって いることを示している. このような計算を他の 8 つの半 径上についても求めて整理したのが Fig. 4 である.

図の各曲線はあるギャップ $r_{\mathrm{g}}$ について前の図（Fig. 3）の $z / r_{\mathrm{a}}$ の大きい方からたどってきて最初に $\pm 0.1 \%$ の 範囲からはずれる点を各半径上に示してある. 即ちこの 曲線の右側の空間の電位分布の理想値からのずれは $\pm 0.1 \%$ 以内である. 従ってこの曲線が $z / r_{\mathrm{a}}$ のより小さ い方にあればそれだけ筒の長さを短くできることを示し ている. ギャップ半径 $r_{\mathrm{g}}$ を最適にするには, 前述の如 く, 単に有効な空間が広いだけではなく, 電子の軌道が この空間に含まれていなければならないので内円筒に近 い方にこの範囲が広がっているよらにすべきである。

Fig. 4 のよらに入射電子の軌道を重ねてみると $r_{\mathrm{g}} / r_{\mathrm{a}}$ の 最適值は1.60から1.63の間にあることがわかる。この間 には, 残念ながら, 計算値がないので大よその補間をし 


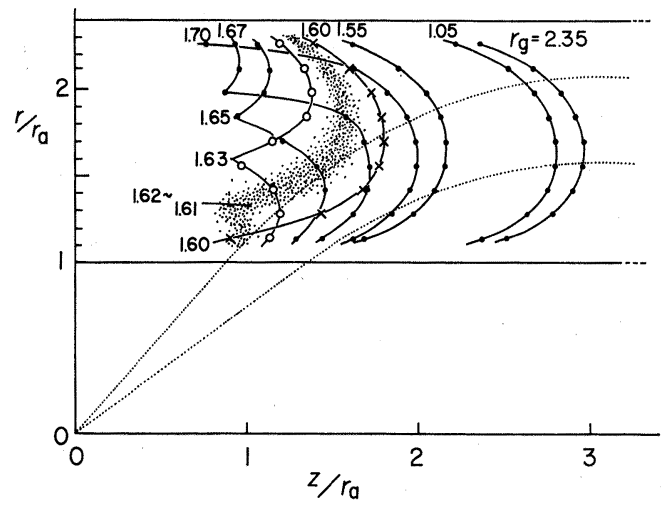

Fig. 4 Regions, right of the curves, which shows $0.1 \%$ of the potential error for the $r_{\mathrm{g}} / r_{\mathrm{a}}$.

てみると, 恐らく $r_{\mathrm{g}} / r_{\mathrm{a}}=1.61 \sim 1.62$ にすれば最適な設計 になるものと思われる．この值を採用すると試料位置は ほぼ $z / r_{\mathrm{a}}=0$, 即ち CMA の長さ（内側）を試料と像の 距離 $\left(6.13 r_{\mathrm{a}}\right)$ まで短くできることがわかる. しかしな がら実際の設計に当っては少々ゆとりをみて試料位置を 端面から約 $0.32 r_{\mathrm{a}}$ だけ内側に入れて安全を期した。 なお 内外円筒の端に近い部分に凹をつけて収束の早さを期待 する試みも行ったが特に記す程のことはなかった．以上 の結果をもとにして設計したのが Fig. 5 であるが,

これは平均的な CMA の特性を目標としている. 試料 からの放出角は $\theta_{\mathrm{c}}=42^{\circ} 18.5^{\prime}$ を中心 $\pm 6^{\circ}$, 電子銃は TV 用のものを改造して中心軸上に配し偏向板を設けて ある. 試料から放出された 2 次電子の一部は 2 次電子コ レクターに開けられた同心円状のスリットを抜けて CMA に入射するが，他のものはコレクターで集められ て増幅され更に試料電流に加算されて 1 次電子ビームの
安定化に用いられる. CMA で分析された電子は同心円 状の出ロスリット（幅68 $\mu \mathrm{m} ）$ に向ら。このスリットは ビームが最も細くなる最適位置にビームとほぼ直角にな るように（Fig. 1 の A-A）して実効エネルギー分解能 $0.25 \sim 0.30 \%$ が得られるようにした. 内円筒の外径 $r_{\mathrm{a}}$ は $27.0 \mathrm{~mm}$, 外円筒の内径 $r_{\mathrm{b}}$ は64.8 $\mathrm{mm}\left(=2.4 r_{\mathrm{a}}\right)$ であ る. 加工精度は50 $\mu \mathrm{m}$ を期待している.この $r_{\mathrm{b}}$ は市販 のもの $\left(r_{\mathrm{b}}=2.2 \sim 2.3 r_{\mathrm{a}}\right)$ に比べて少々大きい值にとっ て“天井を高くし”外円筒に衝突散乱あるいはその為に 生成した二次電子が出カスリットに届きにくい配置にし ている，通過電子のエネルギーを $V_{\mathrm{e}}$ とし外円筒の電位 を $V_{\mathrm{b}}$ また内円筒のそれを $V_{\mathrm{a}}=0$ とすると $V_{\mathrm{e}} / V_{\mathrm{b}} \times \ln \left(r_{\mathrm{b}}\right)$ $\left.r_{\mathrm{a}}\right)=1.30989$ の関係9) があるので, 本研究の例では $V_{\mathrm{b}}$ $=0.6684 V_{\mathrm{e}}$ となる. 出ロスリットを通過した電子は直 接ファラデー・カップ（F.Cup）で補収されてェレクト ロメータで検出するが，比較の為にチャンネルトロンな ども使えるようにしてある. 構成要素の材質は非磁性の SUS-310 S を主に, 銅やアルミ合金を使いコヴァール などの磁性材料は可能な限り避ける。

\section{5. 磁気シールド}

従来より CMA に打ける残留磁場の効果は重要だと言 われながらあまり議論されることはなかったが， VAMAS の委員が複数の研究機関で電磁石を用いた電 子レンズの励磁のみを変えて測定した結果では, 各々の データの間には全く統一性がなくスペクトルの形状・大 きさ・位置が変化することが認められた，市販の CMA には一応ミューメタルのシールドを被せてあるので安心 しがちだが，この効果は少くとも CMAの磁気シールド の端から開口直径分位は中へ進んだあたりから有効にな

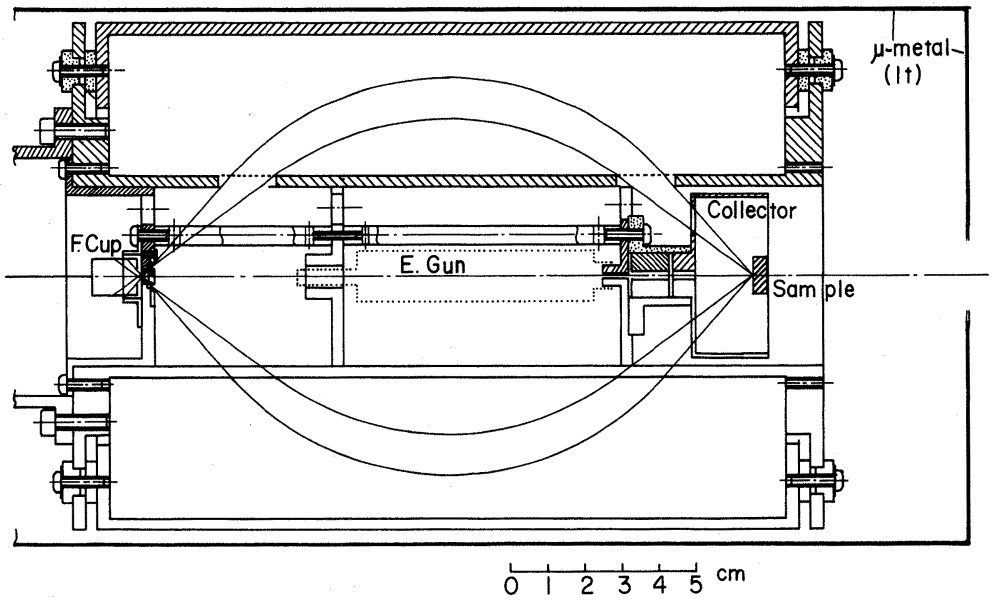

Fig. 5 Design of the new CMA for absolute Auger yield measurements. The radius of the gap (at the center) is $1.62 r_{\mathrm{a}}$. 
るのであって, 試料と CMA の入口の空間は逆にミュー メタルがその周辺からかき集めた磁場が吹出しており何 も施さないときの残留磁場の $2 \sim 3$ 倍に達するところも ある。

磁気シールドの効果は形状の単純な円筒13,14,15) あるい は同軸二重円筒など ${ }^{16,17)}$ そついては数式的に与えられて おり実測值ともよく合う。しかしながら一般的には試行 錯誤に頼らざるを得ないが，製造メーカーは種々の形状 についてデータを持っており参考になる.

磁場の効果は, 例觉ば地磁気の $0.3 \mathrm{G}\left(3 \times 10^{-5} \mathrm{~T}\right)$ の 磁場中をそれと直角方向に $100 \mathrm{eV}$ の電子が走ったとす ると，この電子は半径約 $1.1 \mathrm{~m}$ の円を描く．従って今考 えている CMA について考光てみると，試料からの電子 は約 $20 \mathrm{~cm}$ 飛行して $68 \mu \mathrm{m}$ のスリットを通らねばなら ず，この為には軌道での磁場は $1 \mathrm{mG}$ 以下でなければな らない，これは CMAの軸と垂直な方向の磁場について であるが，軸と平行な成分の効果については電子の半径 方向の成分が軌道の位置により变るので簡単には求まら ないが上記の概算は目安となる。

今回の試作では Fig. 5 亿示すよ5に CMA を含むす ベては磁気シールドの中にあるようにした、磁気シール ドは厚さ $1 \mathrm{~mm} の$ PC（78）材でいわゆるスーパーパー マロイを加工して（株・オータマ）深さ $360 \mathrm{~mm}$, 外径 $144 \mathrm{~mm}$ の円筒に仕上げその片側に直径 $26 \mathrm{~mm}$ の試料導 入用の空を開けたふたをした。この磁気シールドは既に 出来上っているのでこれを用いて実際に地磁気（330 $\mathrm{mG})$ の遮幣効果を磁気シールドの軸と地磁気を平行に したときと直角にしたときについて各々の効果を測定し たのがFig. 6 である.

磁場は F. W. Bell 社モデル620 と平行及び垂直の $2 つ$ のプローブを用いて測定した.シールドの効果は平行に 配置したときの端に近いところを除いては常に中心軸上 の特性が最も劣るのでいずれるこの軸上の特性を示し た. 図中点線と点線の間が CMAの分析空間である. 図 からわかるように GMA の軸と磁場が平行になったと き, 遮幣率は最も悪く, 分析空間での磁場は数 $\mathrm{mG}$ に 減衰している。な括 CMA の配置は機械的な安定性を考 えて水平面に対してその軸が垂直になるように考えてお り，また地磁気は水平と約 $40^{\circ}$ を成しているので実際に はここで得られた值の約 $60 \%$ になるがまだ十分とは言え ない. 従ってシールドを 2 重にするかあるいはへルムホ ルッコイルの併用が必要になる。一方 CMA の軸と磁場 が垂直になるようにすると分析空間は $1 \mathrm{mG}$ 以下にな る.

シールドの内側に配線される大電流（特にフィラメン ト用）によって生じる磁場も無視できない，例えば直径

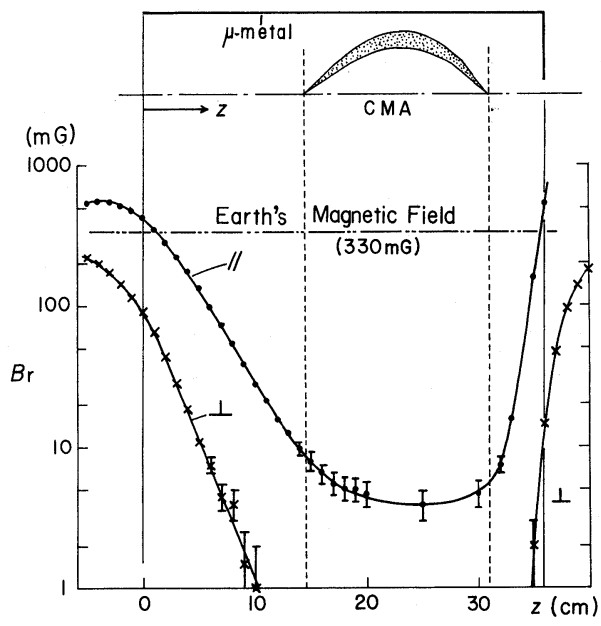

Fig. 6 Magnetic field attenuation characterisitcs of the $\mu$-metal shield, parallel $(/ /)$ and perpendicular to the axis $(\perp)$.

$1 \mathrm{~mm}$ の導線に $1 \mathrm{~A}$ の電流が流れたとすると, そこから 約 $1 \mathrm{~cm}$ 離れたところでのそれによる磁場は $0.2 \mathrm{G}$ にも なり地磁場と同程度になる. 電流の行きと帰りの線を接 近させたり, 撚り合わせたりすれば，相殺効果によりこ の値は小さくなるが，独いCMAの中では補償し切れな いだろう。このような配線には軸精度のよくでている同 軸になった配線を用いて万全を期する必要がある。

\section{6.おわりに}

この研究の目標はAES における定量性の向上のため にVAMAS-SCA の一環として行っているすのであり， ここで設計した CMA を用いてオージェ電子利得を絶対 的な大きさでとら充標準スペクトルを提供するところに ある.この目標の為には CMA があらゆる面からみて最 適であることが判明したので， CMA の機能を可能な限 り忠実に実行できるよう配慮して設計した。

この研究は科学技術庁の科学技術振興調整費の援助を 受けて行っているものであり, 同庁並びに阪大·工・志 水隆一教授を委員長とするVAMAS-SCA の委員の方々 の貴重な御援助と御教示に対し深謝致します，具体的な 設計及び電算機による計算においては日本電子(獭)の最上 明矩氏，林田伸一氏，箕田政顕氏らのコメントと協力に 負らところが大きくここに謝意を表する。

\section{[文献]}

1) P. Auger: Compt. Rend., 177 (1923) 169.

2）後藤敬典, 志水隆一：分光研究，31（1982） 383.

3) C. J. Powell, N. E. Erickson and T. E. Madey: J. 
Electron Spectrosc. Relat. Phenom., 25 (1982) 87.

4) 志水隆一：真空, 30 (1987) 666 .

5）大村卓一ほか：真空, 31 (1988) (744).

6) H. Hafner, J. Arol. Simpson and C. E. Kuyatt: Rev. Sci. Instrum., 39 (1968) 33.

7) H. Z. Sar-El: Rev. Sci. Instrum., 41 (1970) 561.

8) V. V. Zashkvara, M. I. Korsunskii and O. S. Kosmachev: Sov. Phys.-Tech. Phys., 11 (1966) 96.

9) H. Z. Sar-El: Rev. Sci. Instrum., 38 (1967) 1210.

10）北村真一, 関根 哲, 境 悠治: 日本学術振興会 第141委員会資料 No. 598 (1988).
11) P. W. Palmberg, G. K. Bohn and J. C. Tracy: Appl. Phys. Lett., 15 (1969) 254.

12) E. Gisler and E. B. Bas: Vacuum, 36 (1986) 715.

13）柴田猛順, 水橋 清, 柴沼 清, 田中 茂: 真空, 30 (1987) 350.

14）小笠原武, L. Booster：日本物理学会誌，28 (1973) 1041.

15) W. G. Wadey: Rev. Sci. Instrum., 27 (1956) 910.

16) T. E. Sterne: Rev. Sci. Instrum., 6 (1935) 324.

17）福井 清, 奥田健二, 百瀬健一郎 : 電子計測 No. 3 (1973) 61 . 